Nigerian Journal of Technology (NIJOTECH)

Vol. 37, No. 1, January 2018, pp. 71 - 77

Copyright@ Faculty of Engineering, University of Nigeria, Nsukka,

Print ISSN: 0331-8443, Electronic ISSN: 2467-8821

wWw.nijotech.com

http://dx.doi.org/10.4314/njt.v37i1.10

\title{
MICROSTRUCTURAL CHARACTERISATION, PHYSICAL AND CHEMICAL PROPERTIES OF RICE HUSK ASH AS VIABLE POZZOLAN IN BUILDING MATERIAL: A CASE STUDY OF SOME NIGERIAN GROWN RICE VARIETIES
}

\author{
Y. O. Abiodun ${ }^{1, *}$ and A. A. Jimoh ${ }^{2}$ \\ 1 DEPARTMENT OF CiVIL AND ENVIRONMENTAL ENGINEERING, UNIVERSITY OF LAGOS, LAGOS STATE. NiGERIA \\ 2 DePARTMENT OF Civil ENGINEERING, UNIVERSITY OF ILORIN, ILORIN, KWARA STATE. NigERIA \\ 1 yabiodun@unilag.edu.ng, 2aajimoh4real@yahoo.com
}

\begin{abstract}
Recycling of agricultural wastes such as rice husk ash as pozzolan is being increasingly encouraged, particularly in developing countries. In this paper, preliminary investigation on the physical and chemical compositions of rice husk ash using different techniques was carried out. Scanning Electron Microscopy (SEM) images of the rice husk ash showed residual pores to be distributed within the ash sample, indicating that the silica is a highly porous material with a large internal surface area. Samples burnt at $400^{\circ} \mathrm{C}$ for 6 hours and $600^{\circ} \mathrm{C}$ for 4 hours for 'Bukus' and 'Soro/ Olomo nla' show aggregates with clearly defined layers of loose flakes compared to 'Faro 58'. The Energy dispersive $x$ ray spectroscopy (EDX) analysis of rice husk ash performed to determine percentages of silica present in the samples were graphically represented. Nine elements ( $\mathrm{Al}, \mathrm{Si}, \mathrm{K}, \mathrm{Ca}, \mathrm{Br}, \mathrm{Fe}, \mathrm{Mg}, \mathrm{Na}, \mathrm{Mn}$ ) and their corresponding oxides $\left(\mathrm{Al}_{2} \mathrm{O}_{3}\right.$, $\mathrm{SiO}_{2}, \mathrm{~K}_{2} \mathrm{O}, \mathrm{CaO}, \mathrm{Br}, \mathrm{Fe}_{2} \mathrm{O}_{3}, \mathrm{MgO}, \mathrm{Na}_{2} \mathrm{O}, \mathrm{MnO}$ ) were detected with varying concentrations. The three varieties, on the average possess good silica content of over $50 \%$ considering the two varied temperature and time. Therefore, the chemical analysis results show that burning at combustion temperature of $600{ }^{\circ} \mathrm{C} \mathrm{for} 4$ hrs, gives optimal result than at $400^{\circ} \mathrm{C}$ for $6 \mathrm{hrs}$ because all the samples show high Silica content (Faro 58; 61.9, Bukus; 62.6 and Soro/Olomo nla; 59.5).
\end{abstract}

Keywords: Rice husk ash, Scanning electron microscopy, Energy dispersive x-ray spectroscopy

\section{INTRODUCTION}

The use of industrial and bio-organic wastes in concrete as supplementary cementing materials is part of solutions to obtaining a sustainable and healthy environment and also save energy and natural resources. Some of the industrial wastes that are commonly used as supplementary pozzolanic and cementing materials are Rice Husk Ash (RHA), silica fume, fly ash and ash from timber [1]. Rice husk is usually high in ash compared to other biomass fuels. The ash is $87-97 \%$ silica, which is highly porous and light weight, with a very high external surface area and the presence of high amount of silica makes it a valuable material for use in industrial and construction applications [2]. Other constituents of RHA, such as $\mathrm{K}_{2} \mathrm{O}, \mathrm{Al}_{2} \mathrm{O}_{3}, \mathrm{CaO}, \mathrm{MgO}, \mathrm{Na}_{2} \mathrm{O}, \mathrm{Fe}_{2} \mathrm{O} 3$ are available in less than $1 \%$ [3]. Rice husk ash has been widely used in various industrial applications such as processing of steel, cement and construction industry, ceramic and refractory industry. Suitability of RHA as pozzolan in concrete production mainly depends on the chemical composition of the ash, predominantly silica content in it. RHA is found to be superior to other supplementary materials like slag, silica fume and fly ash [4].The cementitious properties exhibited by rice husk ash, a pozzolan, give rise to its consideration as an alternative binder by partial replacement of cement in civil engineering construction works. This will help to reduce the global rising demand in construction materials and increase its sustainability as an agricultural waste, being an annually cultivated crop which could be hazardous to environment if not dispose properly [5]. In this study, the physical and chemical properties of husks from some varieties of rice and their ashes are presented. The experimental program demonstrates the use of Scanning electron microscopy and Energy dispersive x-ray spectroscopy in obtaining the microstructure of the ash and also the chemical composition of the different elements and oxides present in the rice husk ash 
The aim of this research is to investigate the microstructure, physical and chemical properties of Rice husk ash (RHA) from different varieties as viable pozzolan in building material. The specific objectives to determine the chemical composition of the RHA varieties using energy dispersive X-ray Spectroscopy (EDX), analyze microstructure of RHA varieties using scanning electron microscopy (SEM) and identify the physical properties such as colour, length and texture of rice husk $(\mathrm{RH})$ from various sources

\section{MATERIALS AND METHODS}

\subsection{Materials}

Three rice husk samples, collected from different varieties of rice from different locations in Nigeria (Oyo -Faro 58/O.sativa, Katsina -Olomo nla/O.glaberrima and Tsaragi in Kwara - Bukus/ O.glaberrima).

\subsection{Methodology}

The rice husk samples were sun-dried and prepared by burning at $400^{\circ} \mathrm{C}$ for six hours and at $600^{\circ} \mathrm{C}$ for four hours in Morgan ventilated lift-out melting furnace at Kwara polytechnic ICT. The furnace is diesel-fired and in a range of capacities from $250-90 \mathrm{~kg}$ aluminium and $50-100 \mathrm{~kg}$ cast iron. After the burning process was completed, the ash was left to cool inside the furnace for 24-30 hours to room temperature. The burned ash was ground using electric motor grinder and sieved using sieve No. $0.425 \mathrm{~mm}$ to obtain fine texture and to remove impurities like sand from the ash samples. The variation in the raw material composition from different sources gave reason for the necessity of testing the material for their chemical composition.
This was done in order to know the chemical compounds present. The test was carried out in accordance with ASTM C618 - 15 [6]. This investigation was purely a laboratory work carried out at the Material science and Metallurgy laboratory of Kwara State University, Malete (KWASU).

The experimental investigation was carried out using the procedures below;

\section{* Scanning Electron Microscopy (SEM) \\ * $\quad$ Energy Dispersive X-ray spectroscopy (EDX)}

Physical property determination of the rice husk was done using venier caliper, calibrated in mm to measure the length (l) and width (w) of each variety of rice husks.

\section{RESULTS AND DISCUSSIONS}

\subsection{Result of the Chemical analysis of cement and the RHAs}

The summary of the chemical composition of cement and RHA varieties is shown in Table 1 . An analysis of the chemical composition of RHA in Table 1 shows that the high silica, alumina and Iron -oxide contents present are responsible for the pozzolanic activity of RHA. So far RHA is used in combination with either cement or lime as a supplementary cementitious material and the pozzolanic effect of RHA is attributed to the ability of silica to combine with calcium hydroxide to produce cementations compound of calcium silicate hydrates as shown in the equation (1) below [7]

$$
\mathrm{Ca}(\mathrm{OH})_{2}+\mathrm{H}_{4} \mathrm{SiO}_{4} \rightarrow \mathrm{CaH}_{2} \mathrm{SiO}_{4} \cdot 2 \mathrm{H}_{2} \mathrm{O}
$$

Table 1: Chemical Characteristics of cement and rice husk used in this study

\begin{tabular}{|c|c|c|c|c|c|c|c|}
\hline \multirow{2}{*}{ Constituents } & \multirow{2}{*}{ Cement (by weight \%) } & \multicolumn{3}{|c|}{ RHA $\left(600^{\circ} \mathrm{C} / 4 \mathrm{hrs}\right)$ by weight $\%$} & \multicolumn{3}{|c|}{$\mathrm{RHA}\left(400^{\circ} \mathrm{C} / 6 \mathrm{hrs}\right)$ by weight $\%$} \\
\hline & & Faro 58 & Bukus & Soro & Faro 58 & Bukus & Soro \\
\hline $\mathrm{SiO}_{2}$ & 19.34 & 61.9 & 62.6 & 59.5 & 51.1 & 50.4 & 49.7 \\
\hline $\mathrm{CaO}$ & 61.4 & 5.4 & 6.9 & 7.3 & 5.5 & 7.8 & 6.7 \\
\hline $\mathrm{Al}_{2} \mathrm{O}_{3}$ & 4.06 & 1.2 & 3.3 & 2.1 & 1.2 & 1.3 & 1.9 \\
\hline $\mathrm{K}_{2} \mathrm{O}$ & 0.59 & 12.8 & 10.3 & 12.6 & 21.7 & 18.2 & 20.4 \\
\hline $\mathrm{Fe}_{2} \mathrm{O}_{3}$ & 3.08 & 11.4 & 5.1 & 8.8 & 10.8 & 5.3 & 12.8 \\
\hline MgO & 2.34 & 1.4 & 3.4 & 2.2 & 3.1 & 3.5 & 2.3 \\
\hline $\mathrm{Na}_{2} \mathrm{O}$ & 0.48 & 2.1 & 2.5 & 3.0 & 1.7 & 3.4 & 2.0 \\
\hline $\mathrm{SO}_{3}$ & 3.79 & - & - & - & - & - & - \\
\hline $\mathrm{P}_{2} \mathrm{O}_{5}$ & 0.25 & - & - & - & - & - & - \\
\hline Free Lime & 1.5 & - & - & - & - & - & - \\
\hline $\mathrm{Br}$ & - & 2.1 & 3.0 & 2.5 & 1.3 & 7.8 & 2.5 \\
\hline $\mathrm{MnO}$ & - & 1.7 & 2.9 & 2.0 & 3.6 & 2.3 & 1.7 \\
\hline Loss on Ignition & 3.17 & - & - & - & - & - & - \\
\hline
\end{tabular}




\subsection{Result of the Physical characteristics of Rice Husk (RH)}

Table 2 below shows the physical properties of RH varieties used in this study using different parameters like colour, weight per cubic meter, aspect ratio and description. All the varieties of RH are light-weight as a result of their specific gravities $<2.5$.

From Table 2, it can be observed that Faro 58, which is 0. sativa specie has a different identity from others. This could be attributed to its geographical location (Southwest). The average bulk density was of range $362.6-$ $366.5 \mathrm{kgm}^{-3}$ for the long grain rice husk and $328.4 \mathrm{~kg}$ $\mathrm{m}^{-3}$ for the short grain rice husk. The aspect ratio was a measure of the shape and size and was found to be between 2.64 and 3.19. Ratios from 2-3 are categorized as bold while $\leq 2$ are round [1].

\subsection{Result of Physical characteristics of the Rice Husk Ashes}

Table 3 shows result of the specific gravity test carried out on the Oyo/Faro 58 sample of Rice husk ash. Average specific gravity of the ash was found to be 2.36. This is within the expected range of 2.1 to 2.4. The detail of the test results are shown in Table 3 . Thus, it means that using RHA as partial replacements for cement in concrete will produce a greater volume of cementitious material in the concrete because it is less than the value for cement which is 3.15 and because of its high porosity leading to high internal surface area. This value is close to the values of 2.12 for Acha husk ash obtained by Al-Khalaf and Yousif [8]. The value is within the range for pulverized fuel ash (pfa), which is between 1.9 and 2.4 as reported in Neville [9] and the range of 1.67 to 1.94 obtained by Akeke, et al. [10]. Table 4 below shows the general physical properties (colour, texture, mineralogy, size, odour and specific gravity) of three varieties of RHA used.

\subsection{Results on the chemical analysis of Rice husk Ash Samples}

Figure 1 to 6 show the micro structure of the samples tested. Figures 1 and 2 show the microstructure of RHA burnt at a different temperature and time from Oyo at $200 \mu \mathrm{m}$ and accelerating voltage of $15 \mathrm{kv}$. The distance between the microscope and the sample (machine microscope distance / working distance) is $15.9 \mathrm{~mm}$ and $16.1 \mathrm{~mm}$ respectively. The display magnification (the ratio of the area viewed on the screen to the area being scanned on the specimen) is 500. Figures 3 and 4 show the structure of Tsaragi at different temperature and time, while Figures 5 and 6 show the structure of Katsina at different temperature and time. Results from the Energy Dispersive X-ray spectroscopy show the element composition in each sample are shown in Figures 7 - 10 .

Table 2: Characteristics of the rice husk used in this study

\begin{tabular}{|c|c|c|c|c|c|c|}
\hline $\begin{array}{l}\text { Local } \\
\text { name/Species }\end{array}$ & Colour & $\begin{array}{l}\text { Weight per } \\
\text { cubic } \\
\text { meter }\left(\mathrm{kg} / \mathrm{m}^{3}\right) \\
\end{array}$ & $\begin{array}{l}\text { Length, Width } \\
(\mathrm{mm})\end{array}$ & $\begin{array}{l}\text { Aspect } \\
\text { ratio } \\
(1 \div \mathrm{w})\end{array}$ & Description & $\begin{array}{l}\text { Location of } \\
\text { Collection }\end{array}$ \\
\hline Faro 58/ O.sativa & $\begin{array}{l}\text { Yellowish light } \\
\text { brown (buff) BS } \\
381359\end{array}$ & 328.4 & $5.87,2.22$ & 2.64 & $\begin{array}{l}\text { Medium } \\
\text { grained rice, } \\
\text { Bold }\end{array}$ & $\begin{array}{l}\text { Oke-Ogun, } \\
\text { Oyo State }\end{array}$ \\
\hline $\begin{array}{l}\text { Olomo nla/Soro/ } \\
\text { O.glaberrima }\end{array}$ & $\begin{array}{l}\text { Yellowish light } \\
\text { brown(buff) BS } \\
381359\end{array}$ & 362.6 & $7.32,2.29$ & 3.19 & $\begin{array}{l}\text { Long grained } \\
\text { rice, Slender }\end{array}$ & $\begin{array}{l}\text { Katsina, } \\
\text { Katsina State }\end{array}$ \\
\hline $\begin{array}{l}\text { Bukus/ } \\
\text { O.glaberrima }\end{array}$ & $\begin{array}{l}\text { Yellowish light } \\
\text { brown(buff) BS } \\
381359\end{array}$ & 366.5 & $7.02,2.24$ & 3.13 & $\begin{array}{l}\text { Long grained } \\
\text { rice, Slender }\end{array}$ & $\begin{array}{l}\text { Tsaragi, } \\
\text { Kwara State }\end{array}$ \\
\hline
\end{tabular}

Table 3: Specific gravity test result of Rice Husk Ash from Faro 58 at $600^{\circ} \mathrm{C}$ for 4 hours

\begin{tabular}{llll}
\hline Bottle No & A1 & A2 & A3 \\
\hline Wt. of bottle (W1) g & 260.82 & 263.51 & 257.8 \\
Temperature (C) & 30.10 & 30.10 & 29.80 \\
Wt. of bottle+ water+ ash (W2) g & 336.68 & 335.86 & 336.68 \\
Wt. of evaporator dish + dry ash (W3) g & 178.00 & 178.00 & 180.00 \\
Wt. of dish (W4) g & 135.12 & 135.51 & 135.12 \\
Wt. of ash (W5) g & 42.88 & 42.85 & 44.88 \\
Sp. Gravity of water at T $\left({ }^{\circ} \mathrm{C}\right)$ & 0.996 & 0.996 & 0.998 \\
Sp. Gravity of ash & 2.30 & 2.45 & 2.32 \\
AVERAGE SP.GRAVITY & 2.36 & & \\
\hline
\end{tabular}




\section{Microstructural Characterization, Physical and Chemical Properties of Rice ....Y.o. Abiodun \& A.A. Jimoh}

It can be concluded from the SEM and EDX images above that same accelerating voltage of $15 \mathrm{kv}$ was used for all samples to stimulate X-rays from all elements in the sample. This energy was enough to overcome the ionization energy in order to generate the characteristic X-ray. High clarity of images is seen as the working distance decreases. Working distance is the distance between the sample surface and the lower end of the pole piece where the electrons are coming from. Display magnitude of 500 gives a bold picture than 250. Distinct difference was seen in SEM images between samples burnt at $4 \mathrm{hrs} / 600^{\circ} \mathrm{C}$ and $6 \mathrm{hrs} / 400^{\circ} \mathrm{C}$. The height of the X-ray peak (counts) in the spectra (EDX) generated from an SEM is not proportional to the concentration of the element in the sample. However, elements present in major amounts will have major peaks in the spectrum. Result of the chemical composition of the three selected rice husk ash is shown in Table 5.

Table 4: General physical properties of the varieties of Rice husk Ash used in this study

\begin{tabular}{lll}
\hline S/No & Parameters & Properties \\
\hline 1 & Colour & Grey \\
2 & Texture & Fine \\
3 & Mineralogy & Non crystalline(Amorphous) \\
4 & Particle size & $>45$ microns \\
5 & Odour & Odourless \\
6 & Specific gravity & Btw $2.30-2.36$ (for the three varieties) \\
\hline
\end{tabular}

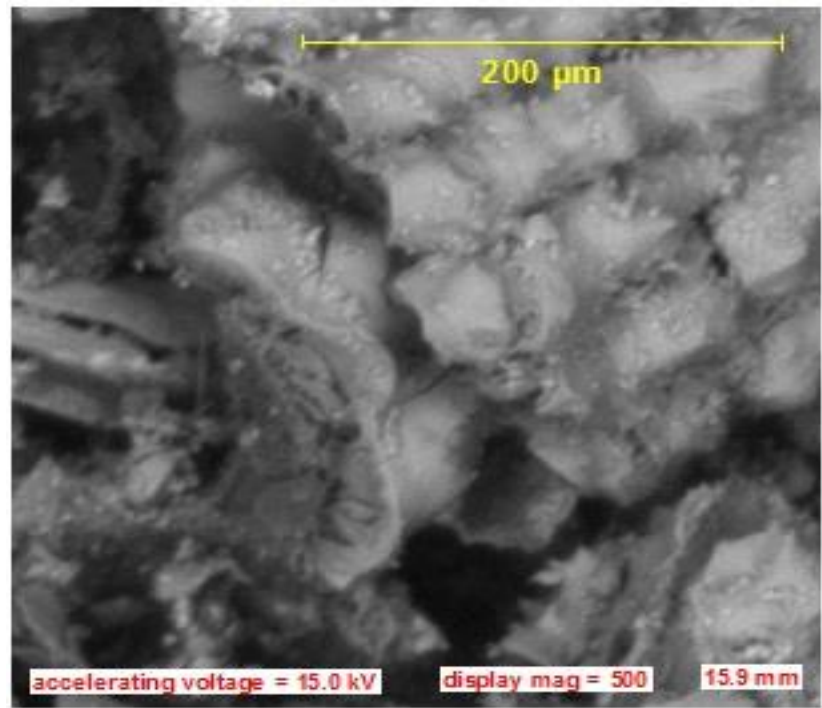

Figure 1: SEM of Faro 58(O.sativa):6hrs@400C

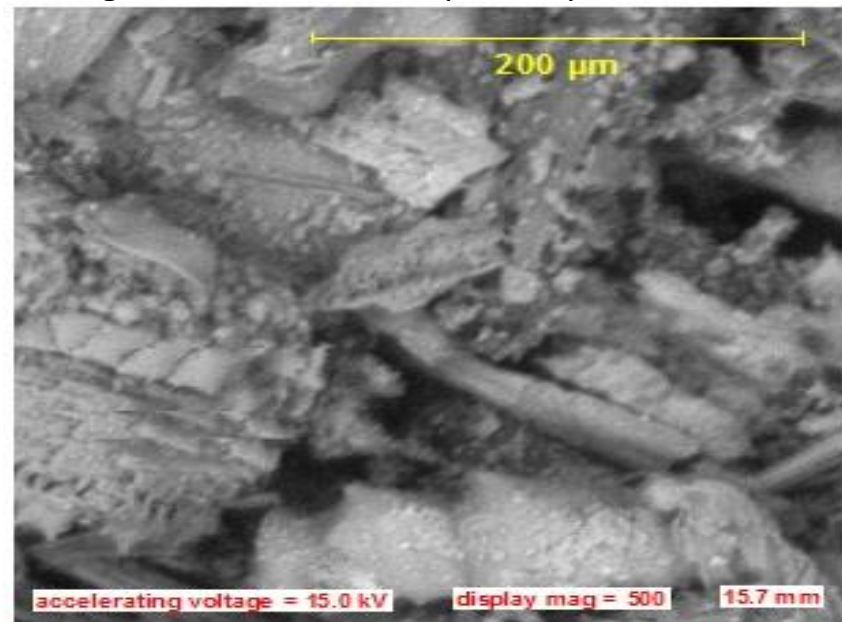

Figure 3: SEM of Bukus (O.glaberrima):6hrs@400C Nigerian Journal of Technology,

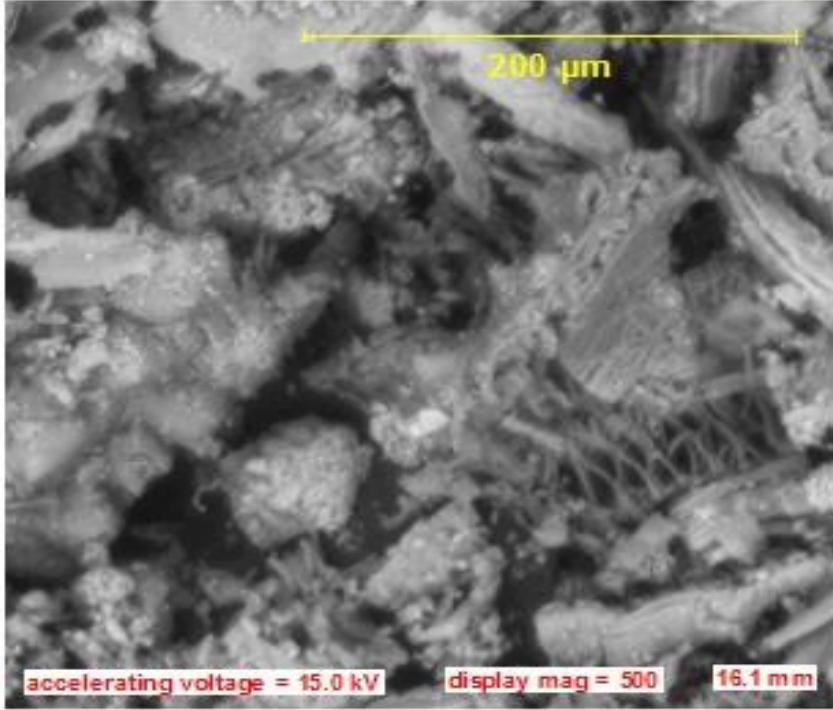

Figure 2: SEM of Faro 58(O.sativa):4hrs@600 C

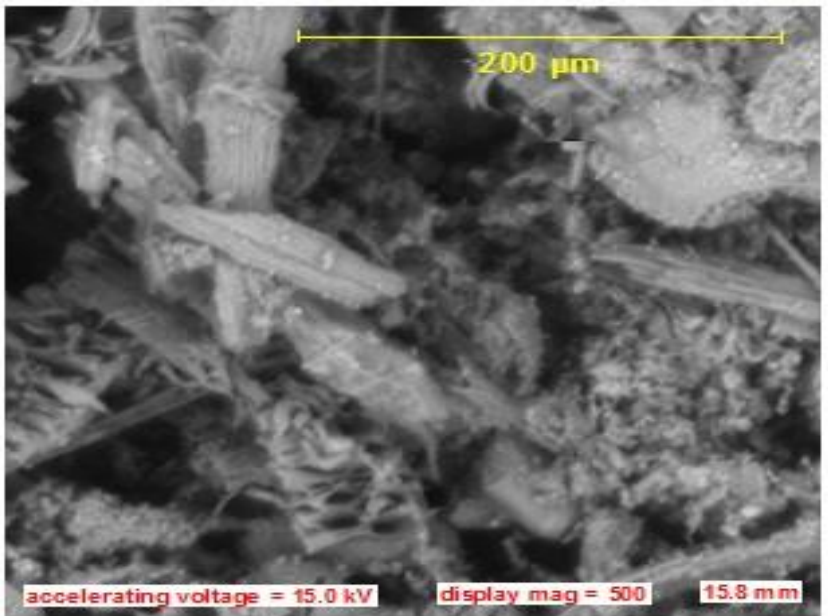

Figure 4: SEM of Bukus (O.glaberrima): 4hrs@600C

Vol. 37, No. 1, January 2017 


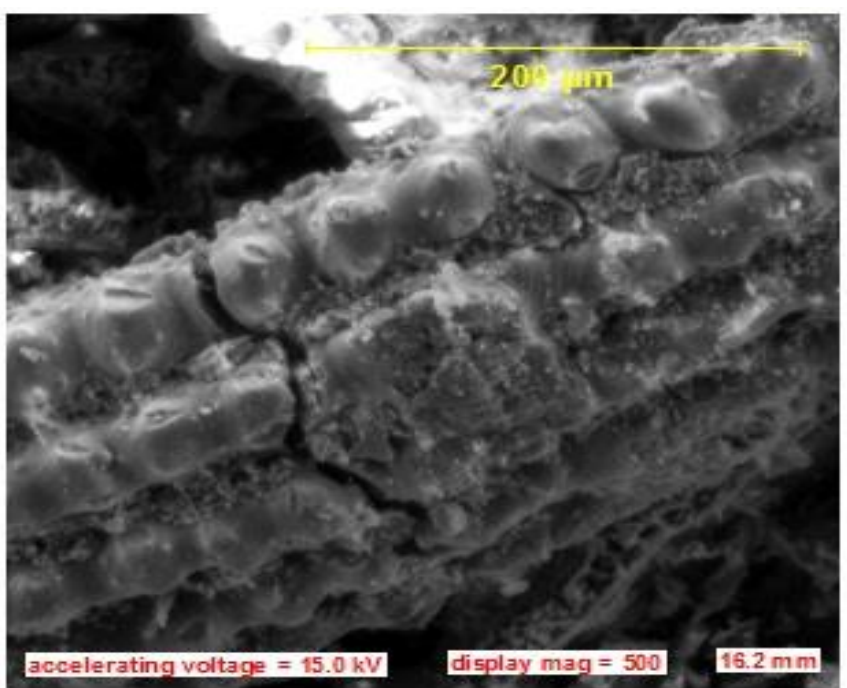

Figure 5: SEM of Soro/Olomo nla (O.glaberrima):4hrs@ $600^{\circ} \mathrm{C}$

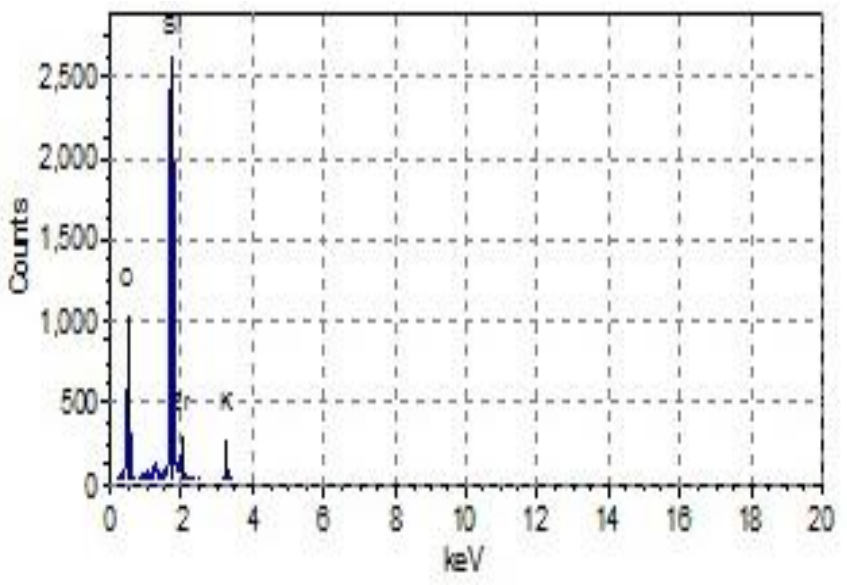

Figure 7: EDX of Faro 58(O.Sativa):6hrs@400C

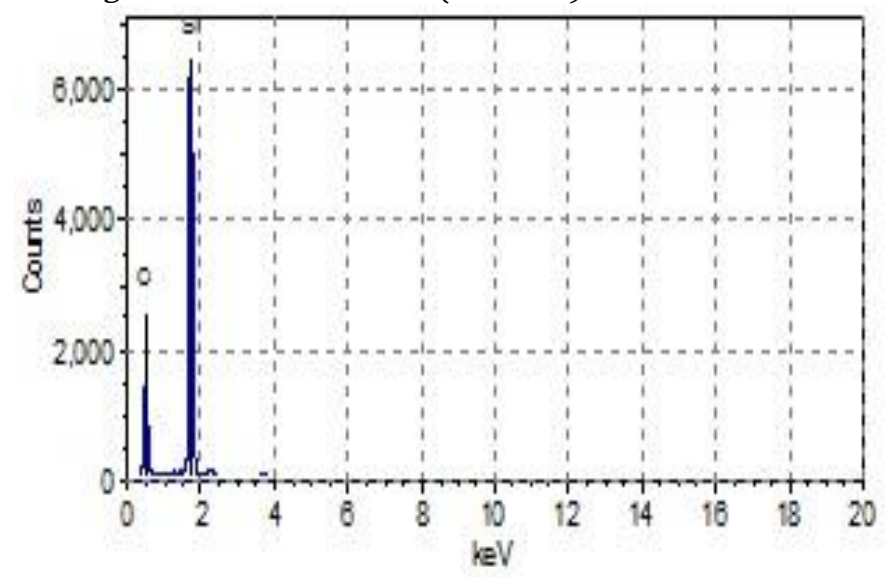

Figure 9: EDX for Bukus (O.glaberrima) :6hrs@400C

The SEM images presented in Figures 1- 6 show that many residual pores are distributed within the ash samples, indicating that the silica is an active and highly porous material with a large internal surface area. The rice husk has been broken down during thermal decomposition of organic matter, thus leaving a highly porous structure. The silica obtained after the burning of rice husk has a grey colour. As the

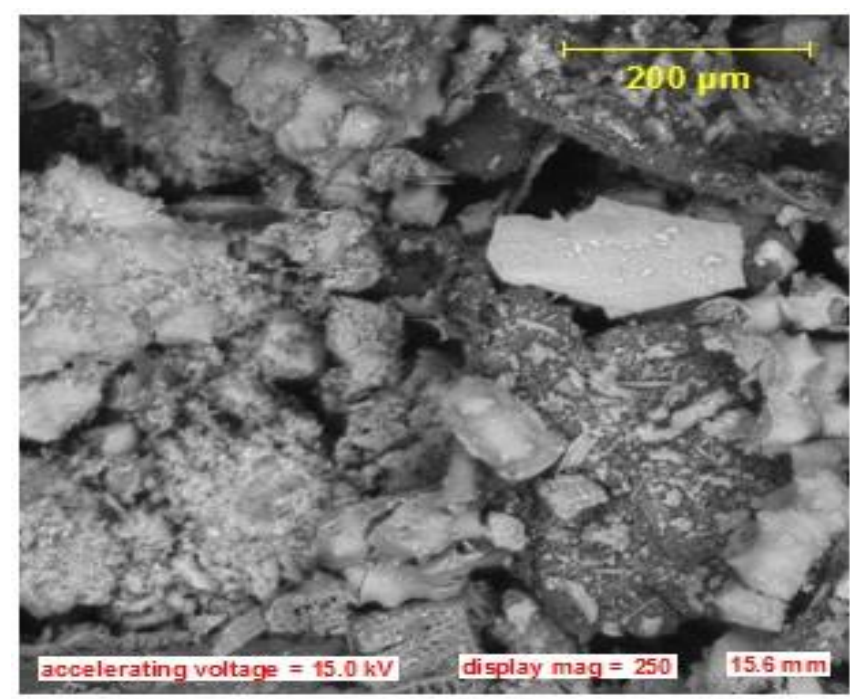

Figure 6: SEM of Soro/Olomo nla (O.glaberrima):6hrs@ $400^{\circ} \mathrm{C}$

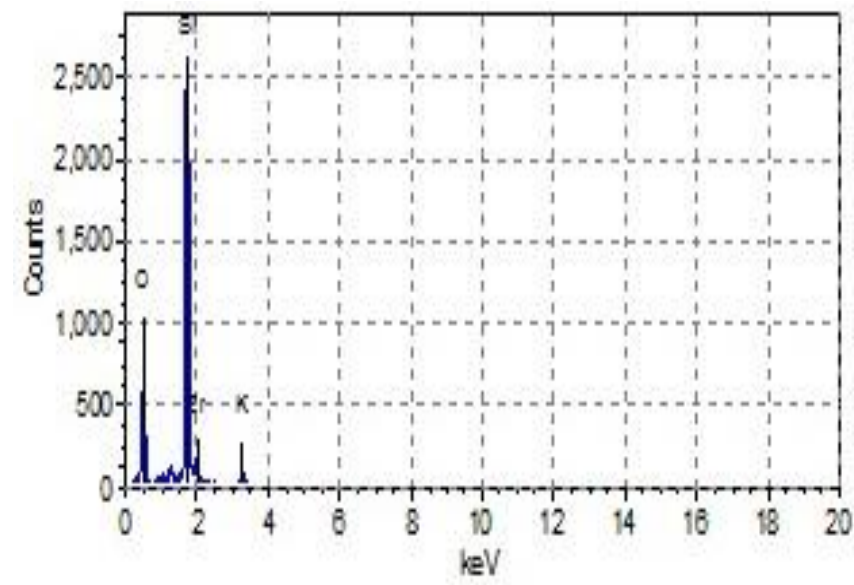

Figure 8: EDX of Faro 58(O.Sativa):4hrs@400C

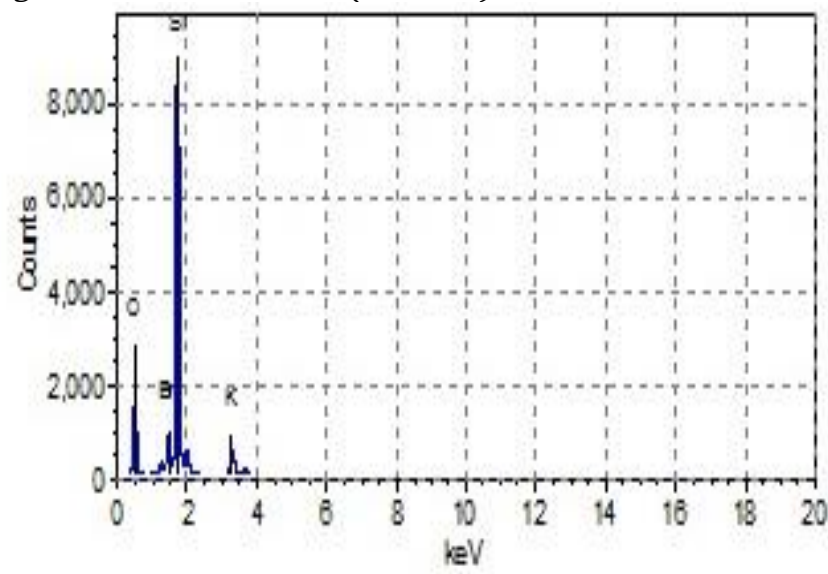

Figure 10 : EDX for Bukus (O.glaberrima):4hrs@600C

temperature of heating increases the loss of volatile matters (Carbonates; $\mathrm{CO}_{2}$ and $\mathrm{CO}$ ) also increases. SEM images of samples burnt at $400^{\circ} \mathrm{C}$ for 6 hours and at $600^{\circ} \mathrm{C}$ for 4 hours show the aggregates with clearly defined layers of loose flakes. The flaky (plate like) morphology of rice husk ash in images suggests that the surfaces are more loosely bound which make them highly amorphous and reactive. 
Microstructural Characterization, Physical and Chemical Properties of Rice ....Y.O. Abiodun \& A.A. Jimoh

Table 5: Chemical composition of the three selected rice husk ash varieties

\begin{tabular}{|c|c|c|c|c|c|c|c|c|c|}
\hline \multicolumn{10}{|c|}{$\%$ Composition $\left(600^{\circ} \mathrm{C} / 4 \mathrm{hrs}\right)$} \\
\hline Elements & $\mathrm{Al}$ & $\mathrm{Si}$ & $\mathrm{K}$ & $\mathrm{Ca}$ & $\mathrm{Br}$ & $\mathrm{Fe}$ & $\mathrm{Mg}$ & $\mathrm{Na}$ & $\mathrm{Mn}$ \\
\hline Oxides & $\mathrm{Al}_{2} \mathrm{O}_{3}$ & $\mathrm{SiO}_{2}$ & $\mathrm{~K}_{2} \mathrm{O}$ & $\mathrm{CaO}$ & $\mathrm{Br}$ & $\mathrm{Fe}_{2} \mathrm{O}_{3}$ & $\mathrm{MgO}$ & $\mathrm{Na}_{2} \mathrm{O}$ & $\mathrm{MnO}$ \\
\hline Faro 58 & 1.2 & 61.9 & 12.8 & 5.4 & 2.1 & 11.4 & 1.4 & 2.1 & 1.7 \\
\hline Bukus & 3.3 & 62.6 & 10.3 & 6.9 & 3.0 & 5.1 & 3.4 & 2.5 & 2.9 \\
\hline Olomo nla & 2.1 & 59.5 & 12.6 & 7.3 & 2.5 & 8.8 & 2.2 & 3.0 & 2.0 \\
\hline \multicolumn{10}{|c|}{$\%$ Composition $\left(400^{\circ} \mathrm{C} / 6 \mathrm{hrs}\right)$} \\
\hline Faro 58 & 1.2 & 51.1 & 21.7 & 5.5 & 1.3 & 10.8 & 3.1 & 1.7 & 3.6 \\
\hline Bukus & 1.3 & 50.4 & 18.2 & 7.8 & 7.8 & 5.3 & 3.5 & 3.4 & 2.3 \\
\hline Olomo nla & 1.9 & 49.7 & 20.4 & 6.7 & 2.5 & 12.8 & 2.3 & 2.0 & 1.7 \\
\hline
\end{tabular}

EDX analysis of the rice husk ash was also performed to determine the percentage of silica present in the samples. Nine elements / oxides were detected in all with varying concentrations. These variations could be due to the differences in the soil density of the locations of collection of the samples, paddy varieties and types of fertilizer used [11]. However, the three varieties contain reasonable amount of silica. The total percentage composition of iron oxide $\left(\mathrm{Fe}_{2} \mathrm{O}_{3}\right)$, Silicon dioxide $\left(\mathrm{SiO}_{2}\right)$ and Aluminum Oxide $\left(\mathrm{Al}_{2} \mathrm{O}_{3}\right)$ at $600^{\circ} \mathrm{C}$ for 4 hours and $400^{\circ} \mathrm{C}$ for 6hours was found to be $74.5 \%$ \& $63.1 \%$ for Faro 58, 71\% \& 57\% for Bukus and $70.4 \% \& 64.4 \%$ for Olomo nla/soro. The values at $600^{\circ} \mathrm{C}$ for 4 hours are within the required value of $70 \%$ minimum for pozzolan [12] and can be classified as class N Pozzolan according to Coker, et al [13]. These values are higher than the $48.36 \%$ value obtained for acha husk ash by Dashan et al [14] and as such, RHA is more pozzolanic but are slightly lower than the $73.15 \%$ value obtained by Oyetola and Abdullah [15]. Therefore the results show that burning at combustion temperature of $600^{\circ} \mathrm{C}$ for 4 hours, gives higher pozzolanic composition than at $400^{\circ} \mathrm{C}$ for 6 hours. Also, because the samples show high Pozzolanic characteristic, it could be adopted for use as partial replacement for cement in this study. Also, from the chemical analysis results of cement and RHA, alumina content was higher in cement (4.06\% byvweight) than in the RHA samples. Higher alumina in cement in form of $\mathrm{C}_{3} \mathrm{~A}$ will lead to widespread construction problems, due to its faster hardening properties [16]. However the alumina content in the RHA falls within the Nigerian Industrial Standard and ASTM specifications [11]. This value is lower than that reported in the work of Oyetola and Abdullahi [15]. The change in colour of RH from light brown to grey after burning also shows that Carbon present in $\mathrm{RH}$ has been removed due to high temperature.

\section{CONCLUSION}

The following conclusions are drawn from the result of the experiment carried out on Rice husk ash from the different locations and of different species.

$>$ The use of RHA as partial replacement of cement in mortar and concrete has been extensively investigated in recent years. Therefore, the results from this study clearly demonstrate that RHA is an effective pozzolan which can contribute to mechanical properties of concrete.

$>$ The relatively high content of Silica shows that rice husk ash that is an agricultural waste can be converted into a valuable product which has so many industrial and domestic applications thereby taking care of disposal problem associated with the husk

\section{RECOMMENDATIONS}

$>$ There are huge amounts of RHA produced as byproduct from the rice processing mills, which are disposed to environment without any return price. Also, a large land area becomes useless and the fertility of land is reduced. This problem can be solved or minimized by properly utilizing RHA for construction purposes because RHA contains a large amount of silica and also exhibits excellent pozzolanic property.

$>$ Government policies should also favour agricultural sector so that more agricultural waste can be discovered and utilized properly

$>$ Incineration with large capacity with a temperature monitoring should be developed

$>$ Further research should be done on RHA with higher burning temperature.

\section{REFERENCES}

[1] Anwar, M., Miyagawa, T. and Gaweesh, M. "Using Rice Husk Ash as a Cement Replacement Material 
in Concrete", Waste Management, Vol. 1, Number 1, 2004, pp. 671-684.

[2] Malhotra, V.M. "Role of Supplementary Cementing Materials and Superplasticizer in Reducing Greenhouse Gas Emissions", ICFRC, Allied Publishers Private Ltd, India, 2010.

[3] Rozainee, M., Ngo, S.P. and Salema, A.A. "Effect of fluidizing velocity on the combustion of rice husk in a bench-scale fluidized bed combustor for the production of amorphous rice husk ash", Bioresource Technology, 4 (6), pp. 703-713, 2008.

[4] Sun, L. "Silicon-Based Materials from Rice Husks and Their Applications", Industrial Engineering Chemistry, Vol. 40, No. 8, pp. 5861-5877, 2001

[5] Alireza, N.G., Suraya, A.R., Farah, N.A. and Mohammad, A.M. "Contribution of Rice Husk Ash to the properties of mortar and concrete: A Review", Journal of American Science, Vol. 6, No. 3, 2010, pp. 235-240.

[6] ASTM C618-15, "Standard Specification for Coal Fly Ash and Raw or Calcined Natural Pozzolan for Use in Concrete", ASTM International, West Conshohocken, PA, www.astm.org /DATABASE. CART/HISTORICAL/C618-15.htm, Accessed on November 12, 2017.

[7] Meddah, M.S. and Tagnit-Hamou, A. "Pore structure of concrete with mineral admixtures and its effect on self-desiccation shrinkage", ACI Mater. J., Vol.106, Number 3, 2009, pp. 241-250

[8] Al-Khalaf, M.N. and Yousif, H.A. "Use of Rice Husk Ash in Concrete", The International Journal of Cement Composites Lightweight Concrete, Vol. 6, Number 4, 1984, pp. 241-248.

[9] Neville, A.M. Properties of Concrete, 5th edition, Longman Scientific and Technical Publishing, London, 2010
[10] Akeke, G.A., Ewa, D.E. and Okafor, F.O. "Effect of variability in the pozzolanic properties of rice husk ash on the compressive strength of concrete", Nigerian Journal of Technology, Vol. 35, No. 4, pp. $694-698,2015$.

[11] Real, C. "Determination of silica from Rich husk ash". J. Am. Ceram. Soc, Vol. 79, Number 8, 1996, pp. $2012-2016$.

[12] ASTM C 618-78, "Specification for fly ash and Raw or Calcium Natural Pozzolana for use as a mineral admixture in Portland Cement Concrete", ASTM International, West Conshohocken, PA, www.astm.org /DATABASE.CART/ HISTORICAL /C618-78.htm, Accessed on November 8, 2017.

[13] Coker, E.B., Sadiku, S., Aguwa, J.I. and Abdullahi, M. "Study of the strength characteristics of proteinbased lightweight foamed concrete with cement partially replaced with rice husk ash", Nigerian Journal of Technology, Vol. 35, Number 4, 2016, pp. 699-706.

[14] Dashan, E. and Khadar, M. "Evaluating the properties of Acha husk ash", International Journal of Science Engineering Technology, Vol.3, Number 4, 2011, pp. 167-171.

[15] Oyetola, E.B. and Abdullahi, M. "The Use of Rice Husk Ash in Low-Cost Sandcrete Block Production", Leonardo Electronic Journal Practices Technology, Vol. 8, 2004, pp. 58-70.

[16] Hewlett, P.C. Lea's Chemistry of Cement and Concrete. 4th Edition, Arnold, London, pp. 299-342, 1998. 